\title{
11: 123491321-123522829
}

National Cancer Institute

\section{Source}

National Cancer Institute. 11:123491321-123522829. NCI Thesaurus. Code C44995.

Physical location of LOH11CR2A_Gene 